\title{
Testicular Involvement in Relapsed Hodgkin Lymphoma
}

\author{
Sinan Demircioğlu ${ }^{1}$, Abdülkadir Baştürk ${ }^{2}$, Aynur Uğur Bilgin ${ }^{1}$ \\ ${ }^{1}$ Department of Hematology, Necmettin Erbakan University Meram School of Medicine, Konya, Turkey \\ ${ }^{2}$ Department of Hematology, Konya Training and Research Hospital, Konya, Turkey
}

Dear Editor,

Malignant lymphoma of the testis generates $5 \%$ of all testicular malignancy and $1 \%$ of all lymphomas (1). Testicular involvement is an extremely rare presentation of Hodgkin's lymphoma (HL); to date, testicular involvement has been reported in 5 patients with HL. We have examined a patient with testicular involvement of HL who relapsed 11 years after treatment. Written informed consent was obtained from patient.

A 40-year-old male patient was admitted to hospital in June 2014 with complaints of fever, weight loss and night sweats for 2 months. We found that he had been diagnosed as mixed cellularity classical HL (stage 2A) in 2003 and achieved complete remission after 3 cycles of Adriamycin (Doxorubicin,
Koçak; Tekirdağ, Turkey), bleomycin (Blemisin, Koçak; Tekirdağ, Turkey), vinblastine (Vinko, Koçak; Tekirdağ, Turkey), dacarbazine (Dakarbaz, Koçak; Tekirdağ, Turkey) (ABVD) chemotherapy and involved field radiotherapy. He was followed without any therapy for 11 years. On admission, physical examination was unremarkable except for millimeter cervical lymph nodes. The following measurements were recorded: erythrocyte sedimentation rate of $97 \mathrm{~mm} / \mathrm{h}$, lactate dehydrogenase level $247 \mathrm{U} / \mathrm{L}$ and beta2-microglobulin of 2.14 $\mathrm{mg} / \mathrm{L}$. 18F-fluorodeoxyglucose (FDG)-positron emission tomography (PET-CT) (Siemens; Munich, Germany) revealed multiple cervical, mediastinal and abdominal lymph nodes with increased FDG uptake. In addition, right $\left(\mathrm{SUV}_{\max }: 20.16\right)$

TABLE 1. Clinical characteristics, pathological features and treatment of patients with testicular Hodgkin's lymphoma in the literature (3).

\begin{tabular}{|c|c|c|c|c|c|c|c|c|}
\hline Author & Age & Clinical information & Site (testis) & HL subtype & $\mathrm{IHC}$ & Stage & Treatment & Outcome \\
\hline Our case & 40 & $\begin{array}{l}\text { Cervical, mediastinal,abdominal mass, } \\
\text { testicular involvement(relapse) }\end{array}$ & Bilateral & $\mathrm{MC}$ & CD15 (+) & IVB & $\begin{array}{c}\mathrm{CT} \\
(6 \mathrm{xABVD})\end{array}$ & $\begin{array}{c}\mathrm{CR} \\
\text { (DFS } 1 \text { years) }\end{array}$ \\
\hline \multirow[t]{2}{*}{$\begin{array}{l}\text { Ben Ameur El Youbi } \\
\text { and Errihani (3) }\end{array}$} & 17 & $\begin{array}{l}\text { Cervical mass, Empty scrotum } \\
\text { (initial involvement) }\end{array}$ & Left & NS & CD15 (+) & & & \\
\hline & & & & & CD30 (+) & IVB & $\begin{array}{l}\text { Orchiectomy }+\mathrm{CT} \\
\qquad(8 \mathrm{xABVD})\end{array}$ & $\begin{array}{c}\text { CR } \\
\text { (DFS } 2 \text { years) }\end{array}$ \\
\hline \multirow[t]{3}{*}{ Gatt et al. (1) } & 73 & $\begin{array}{l}\text { Testicular mass } \\
\text { (initial involvement) }\end{array}$ & Right & NS & $\mathrm{CD} 3(+)$ & IVA & $\begin{array}{l}\text { Orchiectomy } \\
\text { (Not taken } \mathrm{CT})\end{array}$ & Died before $\mathrm{CT}$ \\
\hline & & & & & CD15 (+) & & & \\
\hline & & & & & $\mathrm{CD} 30(+)$ & & & \\
\hline Seliem et al. (2) & 52 & $\begin{array}{c}\text { Testicular mass } \\
\text { (initial involvement) }\end{array}$ & Left & Classical & $\begin{array}{l}\text { CD15 }(+) \\
\text { CD30 }(+)\end{array}$ & IVB & $\begin{array}{c}\text { Orchiectomy }+ \\
\text { CT(4xABVD and } \\
2 \times A V D)\end{array}$ & $\begin{array}{c}\text { CR } \\
\text { (Not reached) }\end{array}$ \\
\hline Glaholm et al. (4) & 56 & $\begin{array}{l}\text { Scrotal pain (initial involvement), } \\
\text { Axillary node }\end{array}$ & Right & $\mathrm{MC}$ & $\mathrm{np}$ & IVA & $\begin{array}{l}\text { Orchiectomy }+\mathrm{CT} \\
(6 \mathrm{xChlVPP})\end{array}$ & $\begin{array}{c}\text { CR } \\
\text { (DFS } 3 \text { years) }\end{array}$ \\
\hline Vishniavsky et al. (5) & 79 & $\begin{array}{c}\text { Inguinal mass } \\
\text { (initial involvement) }\end{array}$ & Right & $\begin{array}{c}\text { Hodgkin } \\
\text { sarcoma (autopsy) }\end{array}$ & y) & - & - & $\begin{array}{l}\text { Died before } \\
\text { treatment }\end{array}$ \\
\hline
\end{tabular}

HL: Hodgkin's lymphoma; IHC: immunohistochemistry; NS: nodular sclerosis; MC: mixed cellularity; np: not performed; CT: chemotherapy; ABVD: doxorubicin, bleomycin, vinblastine, dacarbazine; AVD: doxorubicin, vinblastine,dacarbazine; ChlVPP : chlorambucil, vinblastine procarbazine, prednisolone; CR: complete response; DFS: disease free survival.

This study has been presented at the $41^{\text {st }}$ National Hematology Congress, November 2015, Antalya, Turkey

Address for Correspondence: Dr. Sinan Demircioğlu, Department of Hematology, Necmettin Erbakan University Meram School of Medicine, Turkey

Phone: +90 $5554324474 \quad$ e-mail: sinandemircioglumd@gmail.com

Received: 23 December $2015 \quad$ Accepted: 31 March 2016・DOI: 10.5152/balkanmedj.2016.15165I

Available at www.balkanmedicaljournal.org 
and left $\left(\mathrm{SUV}_{\max }: 19.95\right)$ testicular involvement was observed by PET-CT. Scrotal ultrasound showed a slightly heterogeneous left testicular parenchyma without any mass. The diagnosis of mixed cellularity classical Hodgkin lymphoma was performed with excisional biopsy from mediastinal 41 29 $\mathrm{mm}$ conglomerate lymphadenopathy. In addition, CD30 (+) and CD15 $(+)$ were histologically positive. Stage 4B Hodgkin's lymphoma has been confirmed because of the testicular involvement and the patient has been treated with 6 cycles of ABVD. PET-CT after chemotherapy showed complete metabolic remission.

Testicular involvement of Hodgkin lymphoma is a rare condition. So far, five cases have been reported in the literature. Along with our case, features of a total of 6 cases are shown in Table 1 (1-5). Half of the patients were admitted with testicular mass; however, there were no testicular masses reported in the other patients, or in our case. Unilateral testicular involvement was present in other cases, while bilateral involvement was detected in our case. We did not perform orchiectomy because of the increased FDG uptake in other areas of lymphadenopathies, whereas orchiectomy was performed in other cases. Following chemotherapy, the disappearance of testicular involvement supported our diagnosis. Another feature that distinguishes our case from the others was the presence of testicular involvement in the recurrence of HL; other patients were admitted with testicular mass or involvement at first diagnosis.

Testicular involvement may be due to the directly contiguous spread from adjacent lymph nodes or hematogenous spread (2). In our case, we can assume that testicular involvement is spread hematogenously because there was no lymph node involvement in the adjacent testes. There is no definitive treatment recommendation because of the small number of cases, and ABVD chemotherapy remains a standard treatment in HL. There are also no precise data about the necessity of orchiectomy or central nervous system (CNS) prophylaxis.

As a result, testicular involvement is rare in HL, but should be considered, and orchiectomy should be avoided. There is no definitive information about the prognostic significance of the testicular involvement of Hodgkin's lymphoma because of the inadequate number of these patients and short follow-up times. In the future, we hope to obtain evidence-based information about CNS prophylaxis and the duration of treatment by increasing the number of cases analyzed.

\section{Ethics Committee Approval: N/A}

Informed Consent: Written informed consent was obtained from patient.

Peer-review: Externally peer-reviewed.

Author contributions: Concept - S.D., A.B., A.U.B.; Design - S.D., A.B.; Supervision - S.D.; Resource - S.D., A.B.; Materials - S.D., A.U.B.; Data Collection and/or Processing - S.D.; Analysis and/or Interpretation - S.D., A.B.; Literature Search - S.D., A.B., A.U.B.; Writing - S.D., A.B., A.U.B.; Critical Reviews - S.D., A.U.B.

Conflict of Interest: No conflict of interest was declared by the authors.

Financial Disclosure: The authors declared that this study has received no financial support.

\section{REFERENCES}

1. Gatt N, Falzon S, DeGaetano J, Deguara JM. Testicular mass in an elderly patient: a rare presentation of Hodgkin's lymphoma. BMJ Case Rep 2011;2011.

2. Seliem RM, Chikwava K, Swerdlow SH, Young RH, Ferry JA. Classical Hodgkin's lymphoma presenting as a testicular mass: report of a case. Int J SurgPathol 2007;15:207-12. [CrossRef]

3. Ben Ameur El Youbi M, Errihani H. An unusual presentation of Hodgkin's lymphoma: ectopic testicular involvement. Hematol Oncol Stem Cell Ther 2013;6:124-5. [CrossRef]

4. Glaholm J, Brada M, Horwich A. Hodgkin's disease of the epididymis and testis. J R Soc Med 1989;82:558-9.

5. Vishniavsky S. Hodgkin's sarcoma involving the testicle and adnexa. Va Med Mon (1918) 1973;100:534-7. 